\title{
Studies on Genetic Variability in Genotypes of Blackgram [Vigna mungo (L.) Hepper]
}

\author{
Turfan Khan, R. B. Dubey*, K. K. Nagar and L. L. Bairwa
}

Department of Genetics and Plant Breeding, Rajasthan College of Agriculture, Maharana Pratap University of Agriculture \& Technology, Udaipur (Rajasthan)-313001, India

*Corresponding author

\section{A B S T R A C T}

Genetic variability was studied in 60 genotypes of blackgram. The analysis of variance indicated that the mean sum of square due to genotypes were

\section{Keywords}

Genetic variability, Heritability,

Genetic advance

\section{Article Info}

Accepted:

22 February 2020

Available Online:

10 March 2020 highly significant for all the characters suggesting the presence of good deal of variability in material studied. The estimates of genotypic parameters revealed that differences between the estimates of GCV and PCV were found high for most of the characters. Higher estimates of GCV were observed for seed yield per plant, number of pod per plant, cluster per plant and harvest index. However, maximum heritability was found for 100 -seed weight followed by number of pod per plant and pod length. While, maximum genetic gain was observed for number of pod per plant followed by seed yield per plant. The characters viz., cluster per plant, number of pods per plant, seed yield per plant and harvest index per cent showed high GCV, heritability and genetic gain. Hence, selection can be made for improvement of these characters.

\section{Introduction}

Blackgram [Vigna mungo (L.)Hepper] is an annual, short duration, self pollinated, leguminous crop belong to family leguminoseae sub family Papilionaceae with a chromosome number of $2 n=2 x=22$, it is commonly known as urd bean. Among the various pulses, blackgram is an important one which contains approximately 25-28\% protein, $4.5-5.5 \%$ ash, $0.5-1.5 \%$ oil, $3.5-4.5 \%$ fibre and $62-65 \%$ carbohydrate on dry weight basis (Kaul, 1982). It contains sulphur containing amino acids, methionine and cysteine and also contains lysine, which are excellent component of balanced human nutrition. The blackgram being warm weather crop it is cultivated during Kharif, Rabi and summer seasons in various part of the country. To improve such important pulse 
crop through breeding, study on genetic variability of important traits responsible for seed yield. Knowledge on heritability and genetic advance of the character indicate the scope for the improvement of a trait through selection. Heritability estimates along with genetic advance are also helpful in predicting the gain under selection (Johnson et al., 1955).

\section{Materials and Methods}

The field experiment was conducted at Botany field, Rajasthan College of Agriculture Maharana Pratap University of Agriculture and Technology, Udaipur during Kharif 2017 in Randomised Block Design with three replications using the 56 genotypes along with 4 checks (Table-1). Each treatment will be sown in a plot of $4 \mathrm{~m}$ length. Single row plot maintaining crop geometry of $30 \mathrm{~cm}$ row to row and $10 \mathrm{~cm}$ plant to plant spacing. All the recommended package of practices of zone IVA of Rajasthan will be followed to raise a healthy crop.

Observations will be recorded on Days to 50 $\%$ flowering ,Days to maturity Plant height, Number of primary branches per plant, Number of clusters per plant, Number of pods per cluster, Number of pods per plant, Pod length $(\mathrm{cm})$, Number of seeds per pod, 100 seed weight (g), Biological yield per plant (g), Seed yield per plant (g), Harvest index (\%)Protein content (\%) using five randomly selected plants from each treatment in each replication for all the characters except days to 50 per cent flowering and days to maturity as they will be recorded on plot basis in each replication for each genotype.

The representative bulk sample from each entry in each replication will be used for analysis of protein content. Mean value of 5 plants will be used for statistical analysis.
The data were subjected to statistical analysis for parameters of variability viz., GCV \& PCV, heritability, genetic advance. Variability that existed in the population for various characters was estimated by the method suggested by Burton (1952). Heritability in broad sense was estimated by the formula of Devane and Burton (1953). The genetic advance of the genotypes at 5\% selection pressure was calculated using the formula suggested by Johnson et al., (1955).

\section{Results and Discussion}

\section{Analysis of variance}

The data recorded on fourteen characters were subjected to statistical analysis. The mean sum of squares due to genotypes were highly significant for all the characters studied indicating considerable differences among the genotypes used in the present study (Table 2).

\section{Mean values and range}

The mean performance of genotypes for different characters is presented in Appendix I. A perusal of the data revealed that the range was considerably high for most of the characters viz., days to 50 per cent flowering (37.33 to 45.66 days), days to 75 per cent maturity (69.33 to 82 days), plant height (17.56 to $27.20 \mathrm{~cm})$, number of branches per plant (2.46 to 3.70), number of cluster per plant (7.50 to 16.36), number of pods per cluster (2.05 to 4.34), number of pods per plant (16.66 to 49.60), pod length (3.06 to 5.00 ) number of seeds per pod (5.10 to 8.13), 100-seed weight (3.19to 6.0), biological yield per plant (13 to 28$)$, seed yield per plant (2.26 to 9.50$)$, harvest index per cent (15.30 to 39.76 ), and protein content(21.26 to 24.40) indicating an adequate variability for exercising selection and use in the breeding programmes. 
Genotypic and phenotypic coefficient of variation

The estimates of genotypic parameters revealed that differences between the estimates of GCV and PCV were found high for most of the characters. Higher estimates of GCV were observed for seed yield per plant (25.82\%), number of pod per plant (24.68 $\%)$, cluster per plant (22.42\%) Gowsalya et al., (2016) and harvest index (22.61\%) (Gadakh et al., 2013). Whereas, moderate estimates were found for biological yield per plant height (19.43\%), pod length (14.46\%) and 100-seed weight (17.91\%), number pod per cluster (13.90), plant height $(12.48 \%)$ and low GCV estimates for number of seed per pod $(9.51 \%)$, primary branch per plant $(6.55$ $\%)$, protein content $(4.08 \%)$, days to $50 \%$ flowering $(5.15 \%)$ and days to $75 \%$ maturity (3.53\%) indicating that these traits were mainly governed by additive gene action and are greatly influence for direct selection for genetic improvement by pedigree selection methods of heritable traits. Similar study was also reported by Baranda et al., (2018).

Table.1 List of Genotypes and Checks for use in present study

\begin{tabular}{|c|l|l|}
\hline S. No. & GENOTYPES & SOURCE \\
\hline $\mathbf{1 .}$ & KPU1053 & ARS Kota (Raj.) \\
\hline $\mathbf{2 .}$ & KPU1070 & ARS Kota (Raj.) \\
\hline $\mathbf{3 .}$ & KPU1072 & ARS Kota (Raj.) \\
\hline $\mathbf{4 .}$ & KPU1073 & ARS Kota (Raj.) \\
\hline $\mathbf{5 .}$ & KPU 1074 & ARS Kota (Raj.) \\
\hline $\mathbf{6 .}$ & KPU1078 & ARS Kota (Raj.) \\
\hline $\mathbf{7 .}$ & KPU1079 & ARS Kota (Raj.) \\
\hline $\mathbf{8 .}$ & KPU1080 & ARS Kota (Raj.) \\
\hline $\mathbf{9 .}$ & KPU1081 & ARS Kota (Raj.) \\
\hline $\mathbf{1 0 .}$ & KPU1084 & ARS Kota (Raj.) \\
\hline $\mathbf{1 1 .}$ & KPU1146 & ARS Kota (Raj.) \\
\hline $\mathbf{1 2 .}$ & KPU1147 & ARS Kota (Raj.) \\
\hline $\mathbf{1 3 .}$ & KPU1148 & ARS Kota (Raj.) \\
\hline $\mathbf{1 4 .}$ & KPU1001 & ARS Kota (Raj.) \\
\hline $\mathbf{1 5 .}$ & KPU1088 & ARS Kota (Raj.) \\
\hline $\mathbf{1 6 .}$ & KPU1094 & ARS Kota (Raj.) \\
\hline $\mathbf{1 7 .}$ & KPU1095 & ARS Kota (Raj.) \\
\hline $\mathbf{1 8 .}$ & KPU1097 & ARS Kota (Raj.) \\
\hline $\mathbf{1 9 .}$ & KPU1098 & ARS Kota (Raj.) \\
\hline $\mathbf{2 0 .}$ & KPU1099 & ARS Kota (Raj.) \\
\hline $\mathbf{2 1 .}$ & KPU1143 & ARS Kota (Raj.) \\
\hline $\mathbf{2 2 .}$ & KPU1027 & ARS Kota (Raj.) \\
\hline $\mathbf{2 3 .}$ & KPU129-104 & ARS Kota (Raj.) \\
\hline $\mathbf{2 4 .}$ & KPU1101 & ARS Kota (Raj.) \\
\hline $\mathbf{2 5 .}$ & KPU1102 & ARS Kota (Raj.) \\
\hline $\mathbf{2 6 .}$ & KPU1104 & ARS Kota (Raj.) \\
\hline $\mathbf{2 7 .}$ & KPU1105 & ARS Kota (Raj.) \\
\hline $\mathbf{2 8 .}$ & KPU1107 & ARS Kota (Raj.) \\
\hline $\mathbf{2 9}$ & KPU1108 & ARS Kota (Raj.) \\
\hline $\mathbf{3 0}$ & KPU1109 & ARS Kota (Raj.) \\
\hline $\mathbf{3 1}$ & Pant U40 & ARS Kota (Raj.) \\
\hline $\mathbf{3 2}$ & KPU514-75 & ARS Kota (Raj.) \\
\hline $\mathbf{3 3}$ & KPU1115 & ARS Kota (Raj.) \\
\hline & & \\
\hline
\end{tabular}




\begin{tabular}{|l|l|l|}
\hline $\mathbf{3 4}$ & KPU1116 & ARS Kota (Raj.) \\
\hline $\mathbf{3 5}$ & KPU1120 & ARS Kota (Raj.) \\
\hline $\mathbf{3 6}$ & KPU1121 & ARS Kota (Raj.) \\
\hline $\mathbf{3 7}$ & KPU1122 & ARS Kota (Raj.) \\
\hline $\mathbf{3 8}$ & KPU1123 & ARS Kota (Raj.) \\
\hline $\mathbf{3 9}$ & KPU1124 & ARS Kota (Raj.) \\
\hline $\mathbf{4 0}$ & KPU1125 & ARS Kota (Raj.) \\
\hline $\mathbf{4 1}$ & KPU12-1733 & ARS Kota (Raj.) \\
\hline $\mathbf{4 2}$ & KPU07-08 & ARS Kota (Raj.) \\
\hline $\mathbf{4 3}$ & KPUA14-146 & ARS Kota (Raj.) \\
\hline $\mathbf{4 4}$ & KPU1126 & ARS Kota (Raj.) \\
\hline $\mathbf{4 5}$ & KPU96-3 & ARS Kota (Raj.) \\
\hline $\mathbf{4 6}$ & KPU1128 & ARS Kota (Raj.) \\
\hline $\mathbf{4 7}$ & KPU1132 & ARS Kota (Raj.) \\
\hline $\mathbf{4 8}$ & KPU1134 & ARS Kota (Raj.) \\
\hline $\mathbf{4 9}$ & KPU1135 & ARS Kota (Raj.) \\
\hline $\mathbf{5 0}$ & KPU1137 & ARS Kota (Raj.) \\
\hline $\mathbf{5 1}$ & KPU52-87 & ARS Kota (Raj.) \\
\hline $\mathbf{5 2}$ & KPU52-88 & ARS Kota (Raj.) \\
\hline $\mathbf{5 3}$ & KPU52-89 & ARS Kota (Raj.) \\
\hline $\mathbf{5 4}$ & KPU1138 & ARS Kota (Raj.) \\
\hline $\mathbf{5 5}$ & KPU1139 & ARS Kota (Raj.) \\
\hline $\mathbf{5 6}$ & KPU1144 & ARS Kota (Raj.) \\
\hline $\mathbf{5 7}$ & PU31 (check) & ARS Kota (Raj.) \\
\hline $\mathbf{5 8}$ & PU1 (check) & ARS Kota (Raj.) \\
\hline $\mathbf{5 9}$ & KPU405 (check) & ARS Kota (Raj.) \\
\hline $\mathbf{6 0}$ & KPU524-65 (check) & ARS Kota (Raj.) \\
\hline & & \\
\hline
\end{tabular}

Table.2 Analysis of variance for different characters in blackgram

\begin{tabular}{|c|l|c|c|c|}
\hline SN & Characters & $\begin{array}{c}\text { Replication } \\
{[02]}\end{array}$ & $\begin{array}{c}\text { Genotype } \\
{[59]}\end{array}$ & $\begin{array}{c}\text { Error } \\
{[118]}\end{array}$ \\
\hline $\mathbf{1}$ & Days to 50 per cent flowering & 3.07 & $15.04^{*}$ & 1.43 \\
\hline $\mathbf{2}$ & Days to 75 per cent maturity & 1.85 & $24.23^{*}$ & 2.40 \\
\hline $\mathbf{3}$ & Plant height & 2.06 & $23.09^{*}$ & 1.36 \\
\hline $\mathbf{4}$ & $\begin{array}{l}\text { Number of primary branch per } \\
\text { plant }\end{array}$ & 0.01 & $0.15^{* *}$ & 0.03 \\
\hline $\mathbf{5}$ & Clusters per plant & 1.12 & $20.90^{* *}$ & 0.89 \\
\hline $\mathbf{6}$ & Number of pods per cluster & 0.17 & $0.60^{* *}$ & 0.07 \\
\hline $\mathbf{7}$ & Number of pods per plant & 8.08 & $223.13^{* *}$ & 8.19 \\
\hline $\mathbf{8}$ & Pod length & 0.14 & $1.06^{* *}$ & 0.05 \\
\hline $\mathbf{9}$ & Number of seeds per pod & 0.75 & $1.54^{* *}$ & 0.26 \\
\hline $\mathbf{1 0}$ & 100-Seed weight & 0.27 & $58.41^{* *}$ & 1.56 \\
\hline $\mathbf{1 1}$ & Biological yield per plant & 15.56 & $50.87^{* *}$ & 6.16 \\
\hline $\mathbf{1 2}$ & Seed yield per plant & 0.65 & $6.16^{* *}$ & 0.52 \\
\hline $\mathbf{1 3}$ & harvest index per cent & 5.43 & $124.45^{* *}$ & 10.98 \\
\hline $\mathbf{1 4}$ & Protein content per cent & 0.08 & $2.63^{* *}$ & 0.13 \\
\hline
\end{tabular}

$*$,** Significant at $5 \%$ and $1 \%$ level of significance, respectively 
Table.3 Variability parameters for various characters in blackgram genotype

\begin{tabular}{|c|l|c|c|c|c|c|}
\hline SN & Character & GCV \% & PCV\% & $\mathbf{H}^{\mathbf{2} \%}$ & GA & GG\% \\
\hline $\mathbf{1}$ & Days to 50 \% Flowering & 5.15 & 5.90 & $76.21 \%$ & 3.82 & 9.24 \\
\hline $\mathbf{2}$ & Days to 75 \% Maturity & 3.53 & 4.07 & $75 \%$ & 4.82 & 6.31 \\
\hline $\mathbf{3}$ & Plant Height & 12.48 & 13.61 & $84 \%$ & 5.09 & 23.58 \\
\hline $\mathbf{4}$ & No of Pb/ Plant & 6.55 & 8.45 & $60 \%$ & 0.32 & 10.45 \\
\hline $\mathbf{5}$ & Clusters/ Plant & 22.42 & 23.86 & $88 \%$ & 5.00 & 43.38 \\
\hline $\mathbf{6}$ & No of Pods/ Cluster & 13.90 & 16.59 & $70 \%$ & 0.72 & 24.01 \\
\hline $\mathbf{7}$ & No of Pods/ Plant & 24.68 & 26.06 & $90 \%$ & 16.52 & 48.17 \\
\hline $\mathbf{8}$ & Pod Length & 14.46 & 15.42 & $88 \%$ & 1.12 & 27.95 \\
\hline $\mathbf{9}$ & No of Seeds/ Pod & 9.51 & 12.09 & $62 \%$ & 1.06 & 15.40 \\
\hline $\mathbf{1 0}$ & 100 Seed Weight & 17.91 & 18.63 & $92 \%$ & 8.62 & 35.45 \\
\hline $\mathbf{1 1}$ & Biological Yield/ Plant & 19.43 & 23.10 & $71 \%$ & 6.69 & 33.66 \\
\hline $\mathbf{1 2}$ & Seed Yield/ Plant & 25.82 & 29.18 & $78 \%$ & 2.50 & 47.06 \\
\hline $\mathbf{1 3}$ & harvest Index \% & 22.61 & 25.69 & $78 \%$ & 11.15 & 41.01 \\
\hline $\mathbf{1 4}$ & Protein Content \% & 4.08 & 4.37 & $87 \%$ & 1.76 & 7.83 \\
\hline
\end{tabular}

\section{Heritability}

The estimates of heritability were moderate to high for maximum characters. However, maximum heritability was found for 100-seed weight $(92 \%)$ followed by number of pod per plant $(90 \%)$ and pod length $(88 \%)$. While, maximum genetic gain was observed for number of pod per plant (48.17\%), (Deepshikha et al., 2014), seed yield per plant $(47.06 \%)$ followed by cluster per plant (43.38 $\%)$ and harvest index $(41.01 \%)$. Result indicates that the high heritability estimate indicates less influence of environment on respective characters. Low heritability (broad sense) indicates predominance of nonadditive gene action indicating the scope for breeding. High estimates of GA coupled with substantial amount of heritability indicate that selection for such characters would result in the improvement of characters in the desired direction as the character is governed by additive genes. High heritability coupled with low genetic advance indicates non-additive gene action. The heritability exhibited due to favorable influence of environment rather than genotypes and selection for such traits may not be rewarding. If, low heritability coupled with low genetic advance indicates such character was highly influenced by environment and selection would be ineffective for those traits (Table 3).

\section{References}

Baranda B., Meghawal, D. R., Sharma, P. P. and Sharma, H. (2018) To Estimate Genetic variability Parameters, Correlation and Path Coefficient in Cowpea [Vigna unguiculata (L.) Walp], International Journal of Current Microbiology and Applied Sciences, Special Issue-7: 3013-3023

Burton, G.M. 1952. Quantitative inheritance in grasses. Sixth International Grassland Congress, 1: 277-283.

Deepshikha, Lavanya., G.R. and Kumar, S. 2014. Assessment of genetic variability for yield and its contributing traits in black gram. Trends in Biosciences, 7: 
2835-2838.

Devane, E.M., Burton, G.W. and 1953. Estimating heritability in tall fescue (Festuca arundinacea) from replicated clonal material. Agronomy Journal, 45: 478-481.

Gadakh, S.S., Dethe, A.M., Kathale, M.N. and Kahate, N.S. 2013. Genetic diversity for field and its component traits in green gram [Vigria radiate (L.) Wilczek], 9: 106-109.

Gowsalya, P., Kumaresan, D., Packiaraj, D. and Kannanbapu, J. R. 2016. Genetic variability and character association for biometrical traits in Blackgram [Vigna mungo (L.) Hepper]. Electronic Journal of Plant Breeding, 7: 317-324.

Lush, J.L. 1949. Heritability of quantitative characters in farm animals. Heridates; 35: 356-375.

Singh, A. K., Gautam, R. K., Singh, P.K., Kumar, K., Kumar, N., Swain, S. and Dam Roy, S. 2014. Estimation of genetic variability and association analysis in the indigenous landraces of Urdbean [Vigna mungo (L.) Hepper] of Andaman Islands Vegetos, 27: 113-122.

\section{How to cite this article:}

Turfan Khan, R. B. Dubey, K. K. Nagar and Bairwa, L. L. 2020. Studies on Genetic Variability in Genotypes of Blackgram [Vigna mungo (L.) Hepper]. Int.J.Curr.Microbiol.App.Sci. 9(03): 2736-2741. doi: https://doi.org/10.20546/ijcmas.2020.903.313 